\title{
Hubungan Antara Fasies Batugamping Terhadap Kualitasnya Sebagai Bahan Baku Semen Portland Menurut Kadar CaO dan Senyawa Terkait di Kuari B dan C, PT Indocement Tunggal Prakarsa Tbk Unit Palimanan, Cirebon
}

\author{
Ahmad Syauqi Hidayatillah ${ }^{1 *}$, Rofiatun Khasanah $^{1}$, Tri Winarno ${ }^{1}$ \\ ${ }^{1}$ Departemen Teknik Geologi, Fakultas Teknik, Universitas Diponegoro
}

\begin{abstract}
Abstrak
Batugamping merupakan sumberdaya alam kategori bahan galian industri nonlogam. Penelitian mengenai fasies dan kualitas batugamping di PT Indocement Tunggal Prakarsa Tbk Unit Palimanan dilakukan untuk mengetahui hubungan antara jenis fasies terhadap kualitas batugamping sebagai bahan baku semen Portland. Penelitian dilakukan dengan pengamatan secara makroskopis dan mikroskopis terhadap 20 singkapan batugamping Kuari B dan C. Setiap singkapan batugamping dilakukan pengambilan sampel untuk analisis fasies secara spesifik menggunakan mikroskop dan analisis kualitas kimia menggunakan X-Ray Fluorescence. Hasil analisis menyatakan bahwa batugamping Kuari B diklasifikasikan menjadi 3 fasies, yaitu packstone, bafflestone, dan rudstone yang terbentuk pada zonasi fasies reef core dan back-reef lagoon. Batugamping Kuari C diklasifikasikan menjadi 4 fasies, yaitu mudstone, wackestone, packstone, dan grainstone yang terbentuk pada zonasi fasies back-reef lagoon. Analisis kualitas kimia menunjukkan bahwa semua sampel (8 sampel) batugamping Kuari B berkualitas baik (kadar $\mathrm{CaO}>49 \%$ ), sedangkan pada Kuari $\mathrm{C}$ didapati sebanyak 8 sampel berkualitas baik (kadar $\mathrm{CaO}>49 \%$ ), 2 sampel berkualitas sedang (kadar $\mathrm{CaO} 40-49 \%$ ) dan 2 sampel berkualitas rendah (kadar $\mathrm{CaO}<40 \%$ ). Hasil penelitian menunjukkan bahwa jenis fasies batugamping yang bersifat grainsupported seperti grainstone, packstone, bafflestone, dan rudstone cenderung menghasilkan batugamping dengan kualitas baik, sedangkan fasies batugamping yang bersifat matrix-supported seperti mudstone dan wackestone akan menghasilkan batugamping dengan kualitas yang lebih buruk.
\end{abstract}

Kata kunci: fasies batugamping; semen Portland; kualitas kimia; Palimanan.

\section{Abstract}

Limestone is a natural resource for non-metal industry excavation categories. The research about facies and limestone quality in PT Indocement Tunggal Prakarsa Tbk Unit Palimanan was carried out to determine the relationship between facies types and quality of limestone as a raw material for Portland cement. The study was conducted by observing 20 outcrops of limestone from Quarry B and $C$, macroscopically and microscopically. Each rocks were sampled for specific facies analysis using microscope and chemical quality analysis using X-Ray Fluorescence. The results showed that Quarry $B$ 's limestone is classified into 3 facies: packstone, bafflestone, and rudstone which are formed on facies zonation of reef core and back-reef lagoon. Quarry C's limestone is classified into 4 facies: mudstone, wackestone, packstone, and grainstone which are formed on facies zonation of back-reef lagoon. The chemical quality analysis showed that all samples (8 samples) of Quarry B limestone included in good quality (CaO>49\%), while in Quarry $C$ there were 8 samples which showed good quality (CaO>49\%), 2 samples that showed moderate quality ( $\mathrm{CaO}$ 40-49\%) and 2 samples that showed poor quality ( $\mathrm{CaO}<40 \%)$. The results showed that grain-supported limestone facies like grainstone, packstone, bafflestone, and rudstone are tended to produce good limestone quality, whereas matrix-supported limestone facies like mudstone and wackestone are tended to produce poor quality limestones.

Keywords: limestone facies; Portland cement; chemical quality; Palimanan.

\section{PENDAHULUAN}

Salah satu komponen material yang sangat diperlukan dalam proyek pengembangan infrastruktur adalah semen Portland. Semen Portland adalah bahan perekat material atau agregat pada proses pembuatan beton (Ahmad, 2014). Batugamping dalam hal ini merupakan bahan baku utama dalam pembuatan semen Portland. Dalam eksplorasi batugamping sebagai bahan baku semen Portland, dibutuhkan analisis 
mengenai persebaran batugamping yang memiliki kualitas tinggi. Tinggi rendahnya kualitas batugamping sebagai bahan baku semen Portland ini sebagian besar dipengaruhi oleh kadar CaOnya. Di sisi lain, batugamping sendiri memiliki karakteristik yang berbeda-beda bergantung dari fasies batugamping tersebut berada. Untuk mempermudah eksplorasi bahan baku semen Portland, pada penelitian ini akan dicari hubungan fasies batugamping mana yang memiliki kadar Cao yang tertinggi.

Penelitian dilakukan di Kuari B dan C lokasi tambang batugamping PT Indocement Tunggal Prakarsa Tbk Unit Palimanan, Cirebon yang terletak di Desa Kedungbunder, Kecamatan Palimanan, Kabupaten Cirebon, Provinsi Jawa Barat. Maksud dari penelitian ini yaitu untuk mengetahui kondisi geologi, jenis fasies dan zonasi fasies batugamping, persebaran kualitas batugamping dan keterkaitan antara jenis fasies terhadap kualitas batugamping di daerah penelitian.

Daerah penelitian termasuk dalam fisiografi Zona Bogor bagian timur (van Bemmelen, 1949). Zona Bogor merupakan suatu antiklinorium yang cembung ke utara dengan arah sumbu lipatan barat - timur. Daerah penelitian Kuari B dan C tersusun dari 2 jenis formasi batuan yaitu Formasi Cibulakan Atas dan Formasi Parigi. Formasi Cibulakan Atas terbagi menjadi 3 anggota (Arpandi dan Padmosukismo, 1975) yaitu Anggota Masif yang terdiri dari perselingan batulempung dengan batupasir berukuran halus sedang, Anggota Utama yang terdiri dari perselingan batulempung dengan batupasir berukuran halus - sedang dan bersifat glaukonitan, serta Anggota Pre-Parigi yang tersusun dari litologi perselingan batugamping, dolomit, batupasir dan batulanau yang terendapkan secara selaras di atas Anggota Utama.

Formasi Parigi tersusun dari mayoritas batugamping berwarna abu-abu terang yang mengandung fosil, berpori dan terdapat sedikit dolomit. Pada formasi ini juga didapati adanya batuserpih karbonatan dan napal pada bagian bawah. Pada Formasi Parigi didapati adanya batugamping terumbu namun ketebalannya berbeda pada beberapa tempat dan berselingan dengan napal.

Pada penelitian ini penentuan geomorfologi dilakukan dengan didasarkan pada klasifikasi Brahmantyo dan Bandono (2006) untuk pemeta-

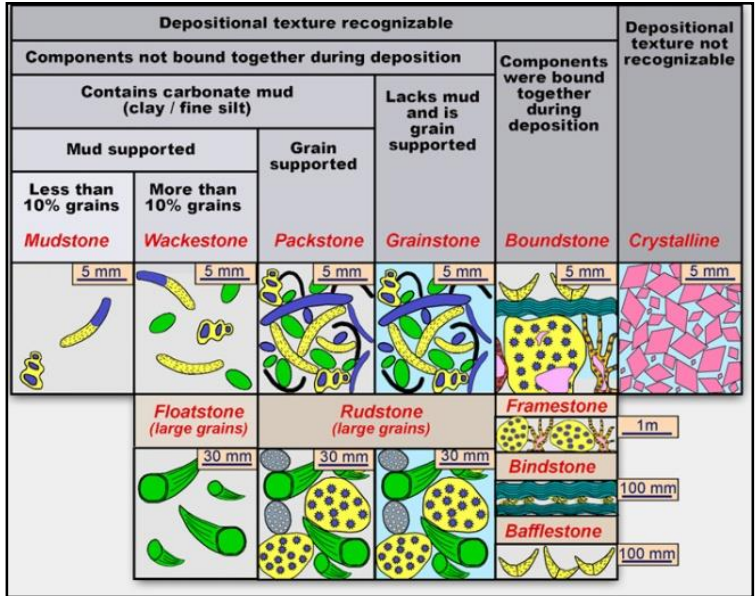

Gambar 1. Klasifikasi batugamping Embry dan Klovan, 1971 dengan modifikasi (Loucks dkk., 2003).

an kawasan detail skala 1:5.000. Penentuan jenis fasies dan zonasi fasies batugamping didasarkan pada klasifikasi Embry dan Klovan (1971) seperti yang terlihat pada Gambar 1, serta Pomar dkk. (2004) untuk zonasi fasies. Penentuan kualifikasi kualitas batugamping sebagai bahan baku semen didasarkan pada klasifikasi kualitas batugamping berdasarkan kadar CaO PT Indocement Tunggal Prakarsa Tbk Unit Palimanan oleh Purwoto dkk. (2011) serta SNI-15-2049-2004 seperti yang terlihat pada Tabel 1 dan Tabel 2.

\section{METODOLOGI}

Penelitian ini menggunakan metode pemetaan geologi meliputi pemetaan geomorfologi, litologi, struktur geologi serta analisis laboratorium berupa analisis fasies batugamping dan analisis kandungan kimia. Pemetaan geologi dilakukan terhadap 23 stasiun pengamatan. Analisis geomorfologi di sini dilakukan untuk memberikan informasi mengenai kondisi morfologi daerah penelitian yang akan ditambang. Pemetaan litologi dan struktur geologi dilakukan untuk memberikan gambaran persebaran litologi dan struktur yang ada di daerah penelitian.

Pada analisis laboratorium dilakukan pengamatan sayatan tipis menggunakan mikroskop polarisasi untuk mengenali fasies batugamping yang ada. Analisis kandungan kimia dilakukan dengan menggunakan metode $X$ Ray Fluorescence. Metode X-Ray Fluorescence adalah metode instrumental non-destruktif dari analisis kualitatif dan kuantitatif untuk unsurunsur kimia berdasarkan pengukuran intensitas 
Tabel 1. Klasifikasi kualitas batugamping berdasarkan kadar $\mathrm{CaO}$ PT Indocement Tunggal Prakarsa Tbk Unit Palimanan (Purwoto dkk., 2011).

\begin{tabular}{cc}
\hline $\begin{array}{c}\text { Persentase Kadar } \\
\mathrm{CaO}\end{array}$ & $\begin{array}{c}\text { Kategori Kualitas } \\
\text { Batugamping }\end{array}$ \\
\hline$>49 \%$ & Baik \\
$40-49 \%$ & Sedang \\
$<40 \%$ & Buruk
\end{tabular}

Tabel 2. Syarat kimia utama semen SNI-15-20492004 (Badan Standardisasi Nasional, 2004).

\begin{tabular}{|c|c|c|c|c|c|c|}
\hline \multirow{3}{*}{ No. } & \multirow{3}{*}{ Uraian } & \multicolumn{5}{|c|}{ Jenis Semen Portland } \\
\hline & & $\mathrm{I}$ & II & III & & V \\
\hline & & \multicolumn{5}{|c|}{ Satuan dalam \% } \\
\hline 1. & $\mathrm{SiO}_{2}$, minimum & & 20 & - & - & - \\
\hline \multirow{5}{*}{$\begin{array}{l}2 . \\
3 . \\
4 . \\
5 .\end{array}$} & $\mathrm{Al}_{2} \mathrm{O}_{3}$, maksimum & - & 6,0 & - & - & - \\
\hline & $\mathrm{Fe}_{2} \mathrm{O}_{3}$, maksimum & & 6,0 & - & 6,5 & . \\
\hline & $\mathrm{MgO}$, maksimum & 6,0 & 6,0 & 6,0 & 6,0 & 6,0 \\
\hline & $\begin{array}{l}\mathrm{SO}_{3} \text {, maksımum } \\
\text { Jika } \mathrm{C}, \mathrm{A} \leq 8.0\end{array}$ & 30 & 30 & 35 & 23 & 23 \\
\hline & Jika $C_{3} A>8,0$ & 3,5 & & 4,5 & & \\
\hline \multirow{2}{*}{$\begin{array}{l}6 . \\
7 .\end{array}$} & Hilang pijar, maksimum & 5,0 & 3,0 & 3,0 & 2,5 & 3,0 \\
\hline & $\begin{array}{l}\text { Bagian tak larut, } \\
\text { maksimum }\end{array}$ & 3,0 & 1,5 & 1,5 & 1,5 & 1,5 \\
\hline \multirow{5}{*}{$\begin{array}{l}8 . \\
9 . \\
10 . \\
11 .\end{array}$} & $\mathrm{C}_{3} \mathrm{~S}$, maksimum & - & - & - & 35 & - \\
\hline & $\mathrm{C}_{2} \mathrm{~S}$, minimum & - & - & - & 40 & 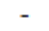 \\
\hline & $\mathrm{C}_{3} \mathrm{~A}$, maksimum & - & 8,0 & 15 & 7 & 5 \\
\hline & $\mathrm{C}_{2} \mathrm{AF}+\mathrm{C}_{2} \mathrm{~F}$, & - & - & - & - & 25 \\
\hline & maksimum & & & & & \\
\hline
\end{tabular}

garis spektrum sinar-X yang dipancarkan oleh eksitasi sekunder (Hewlett dan Liska, 2019).

Metode X-Ray Fluorescence ini dipilih karena metode ini mudah dilakukan, cepat, murah, serta telah cukup presisi untuk mengetahui kandungan kimia dari batuan yang diteliti seperti yang telah dikemukakan oleh Wheeler (1999). Analisis kandungan kimia menggunakan X-Ray Fluorescence pada batugamping telah banyak dilakukan seperti pada penelitian Nurwaskito dkk. (2015), Permana (2018), Marin dkk. (2019), Parorak dkk. (2019), Hewlett dan Liska (2019) dan sebagainya. Analisis fasies dan kualitas dilakukan terhadap 8 sampel batugamping Kuari B dan 12 sampel batugamping Kuari C.

\section{HASIL}

\section{Kondisi Geologi}

Penelitian ini dilakukan terhadap Kuari B dan C lokasi penambangan batugamping PT Indocement Tunggal Prakarsa Tbk Unit Palimanan, Cirebon. Peta lintasan penelitian ditampilkan pada Gambar 2.

\section{Kondisi Geologi Kuari B}

Kuari B tersusun dari geomorfologi Punggungan Antiklin Kromong dan Bukit Intrusi
Kromong. Litologi pada kuari ini terdiri dari batulempung karbonatan, batugamping, dasit dan tuf. Struktur geologi yang ditemui yaitu berupa kekar dan perlapisan miring dengan strike/dip $\mathrm{N} 111^{\circ} \mathrm{E} / 46^{\circ}$ yang merepresentasikan sayap lipatan (Gambar 3).

\section{Kondisi Geologi Kuari C}

Kuari $\mathrm{C}$ tersusun dari geomorfologi Punggungan Antiklin Kromong dan Bukit Intrusi Kromong dengan litologi batulempung karbonatan, batugamping, dan andesit. Struktur geologi berupa kekar, sesar normal, dan perlapisan miring $\mathrm{N} 105^{\circ} \mathrm{E} / 40^{\circ}$ (selatan), $\mathrm{N} 15^{\circ} \mathrm{E} / 46^{\circ}$ (timur), dan $\mathrm{N} 285^{\circ} \mathrm{E} / 34^{\circ}$ (barat) yang merepresentasikan sebuah lipatan (Gambar 3)

\section{Hasil Analisis Fasies Batugamping}

Hasil analisis menunjukkan bahwa batugamping Kuari B dan C tergolong dalam 6 fasies secara keseluruhan yaitu bafflestone, rudstone, grainstone, packstone, wackestone dan mudstone. Hasil zonasi (Gambar 4) menunjukkan bahwa fasies batugamping di Kuari B termasuk ke dalam zonasi reef core hingga outer back-reef lagoon. Sedangkan fasies batugamping di Kuari $\mathrm{C}$ termasuk ke dalam zonasi outer dan inner back-reef lagoon menurut klasifikasi zonasi fasies Pomar (2004) (Gambar 4). Peta persebaran jenis fasies batugamping ditampilkan pada Gambar 5.

\section{Fasies Batugamping Kuari $B$}

Penelitian terhadap 8 sampel batugamping Kuari B menunjukkan bahwa daerah penelitian Kuari B setidaknya tersusun dari 3 jenis fasies yaitu packstone, bafflestone dan rudstone. Berdasarkan zonasi fasies Pomar (2004), keberadaan fasiesfasies tersebut mengindikasikan batugamping di Kuari B terbentuk di zona reef core hingga outer back-reef lagoon. Fasies packstone ditemukan pada sampel STA 1B (Gambar 6), 2B, 4B, 5B dan 9B. Fasies ini dicirikan oleh batugamping abuabu kehitaman, berstruktur masif, keras, dan tersusun dari fragmen material klastik. Tekstur ukuran butir mulai dari $2-3 \mathrm{~mm}$ dengan komposisi batuan terdiri dari porositas $\pm 4 \%$, sparit kalsit $\pm 7 \%$, mikrit $\pm 41 \%$, alga hijau $\pm 38 \%$ dan foraminifera $\pm 10 \%$. Fragmen alga hijau dan foraminifera dalam batuan ini bukan lagi berupa cangkang utuh tetapi sudah tergantikan oleh mineral kalsit. 


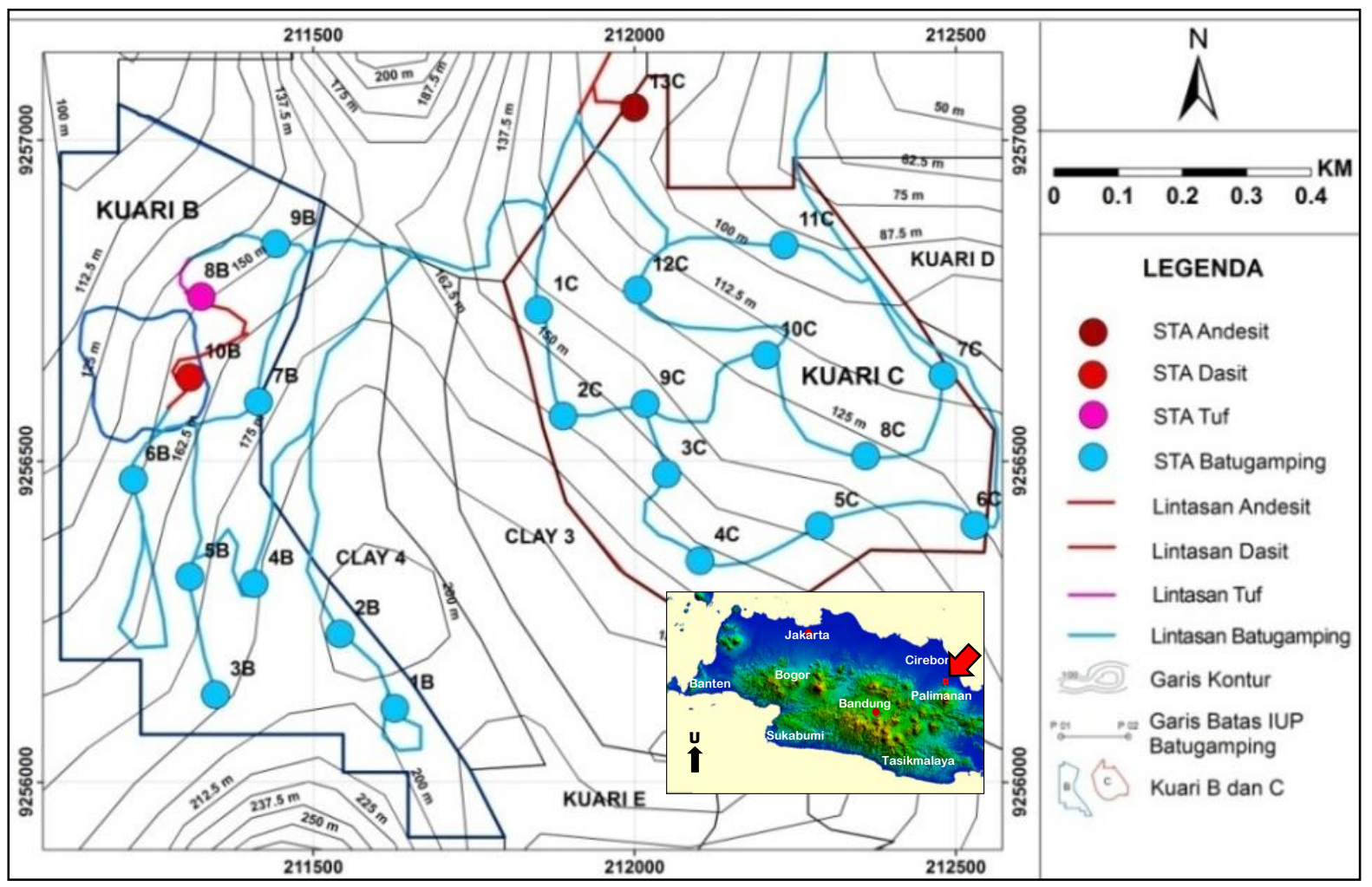

Gambar 2. Peta lintasan dan persebaran stasiun pengamatan geologi Kuari B dan C.

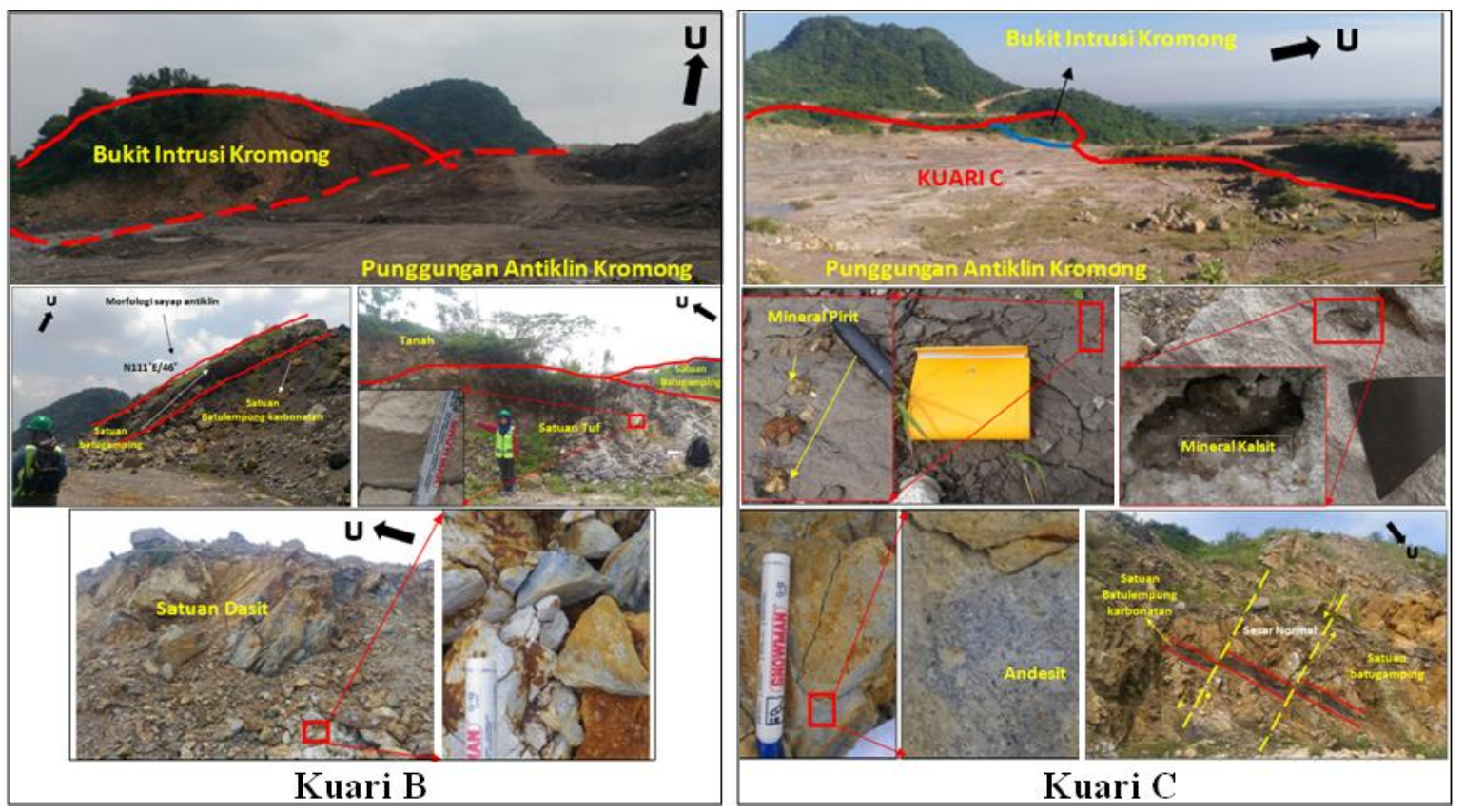

Gambar 3. Kondisi geologi Kuari B dan C. 


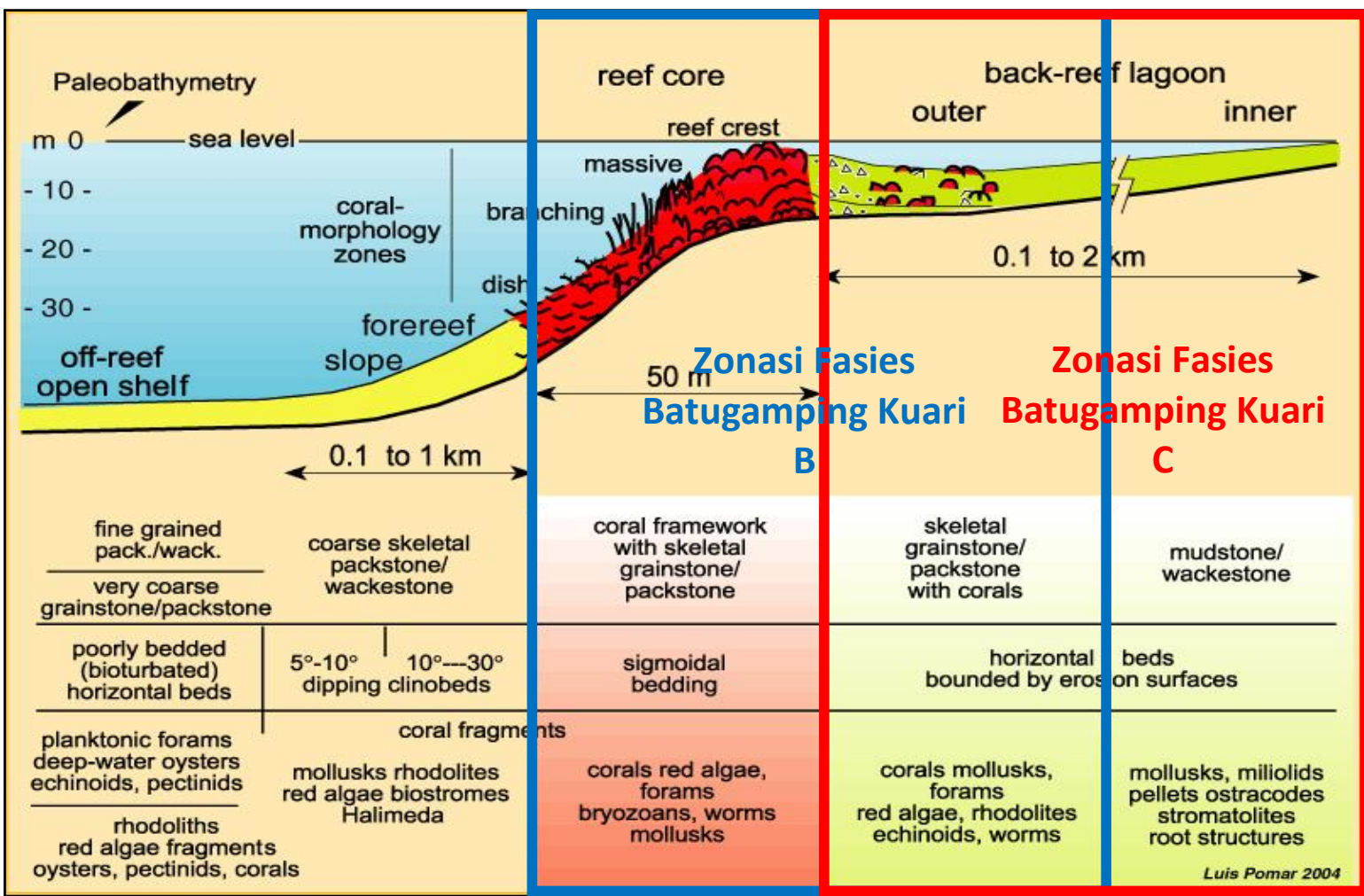

Gambar 4. Hasil zonasi fasies batugamping Kuari B dan C (Pomar, 2004 dengan modifikasi).

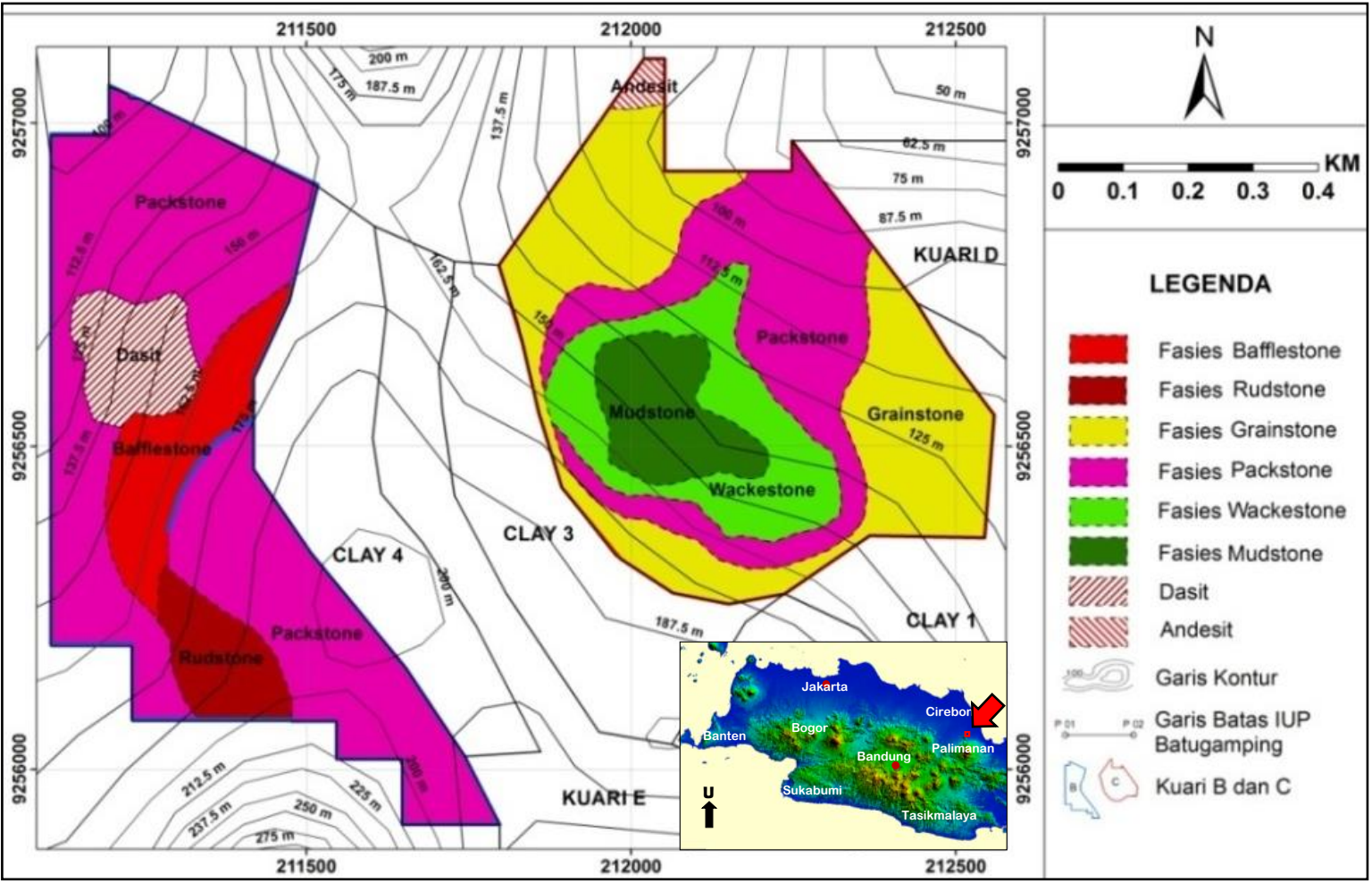

Gambar 5. Peta persebaran fasies batugamping Kuari B dan C. 


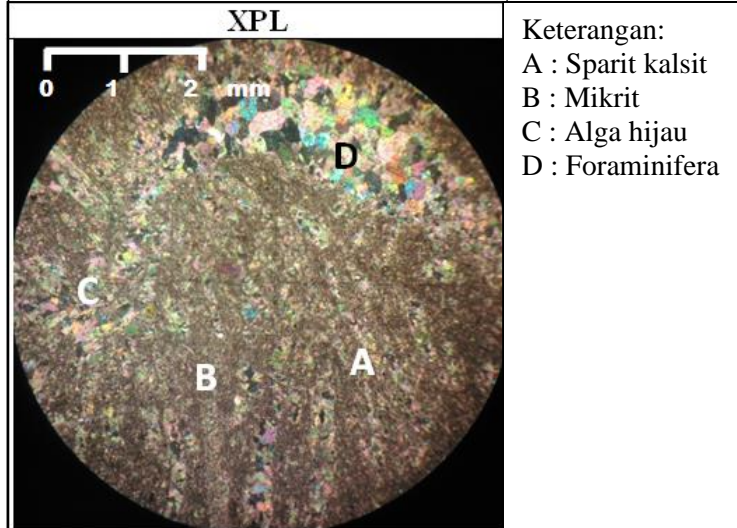

Gambar 6. Kenampakan fasies packstone pada sampel STA 1B secara mikroskopis.

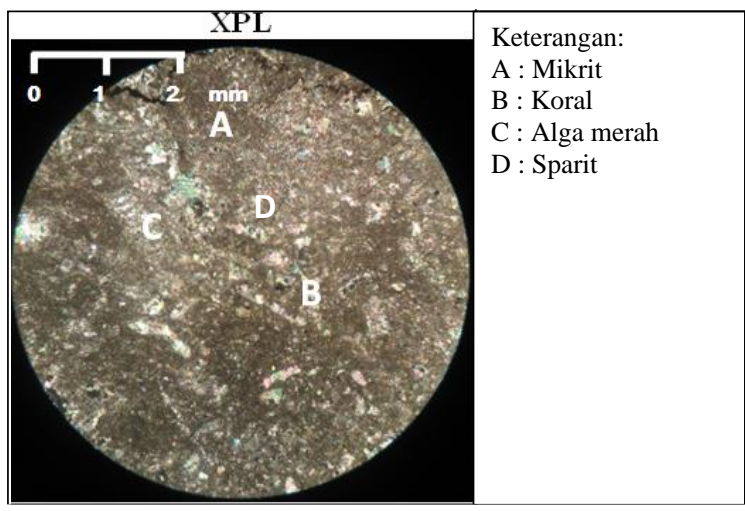

Gambar 8. Kenampakan matriks fasies rudstone pada sampel STA 3B secara mikroskopis.

Fasies bafflestone ditemukan pada sampel STA 6B dan 7B (Gambar 7). Fasies ini dicirikan oleh batugamping abu-abu kehitaman, berstruktur masif, tersusun dari material terumbu secara dominan dan material cangkang organisme lain. Batuan ini memiliki tekstur yang sangat kasar dimana branching coral ditemui dengan bentuk memanjang dan melimpah. Koral tersebut kemudian tertimbun oleh lumpur karbonat atau mikrit dalam jumlah yang cukup melimpah sehingga menyebabkan kesan warna batuan menjadi gelap. Batuan ini memiliki kekerasan yang cukup tinggi karena komposisi batuan saling terekat erat.

Fasies rudstone ditemukan pada sampel STA 3B (Gambar 8). Fasies ini dicirikan oleh adanya batugamping putih kekuningan, struktur berlapis, dan tersusun dari fragmen material klastik. Fasies ini memiliki komposisi fragmen cangkang organik berupa moluska dan branching coral yang melimpah dan memiliki ukuran yang sangat besar, bahkan hingga mencapai $10 \mathrm{~cm}$.

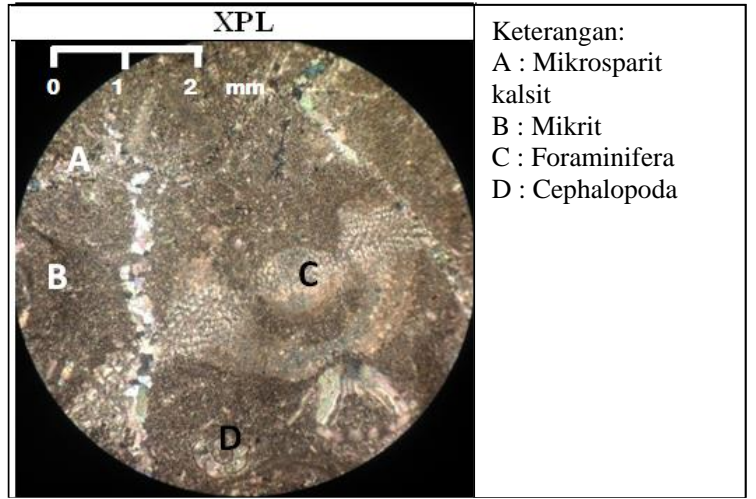

Gambar 7. Kenampakan matriks fasies bafflestone pada sampel STA 6B secara mikroskopis.

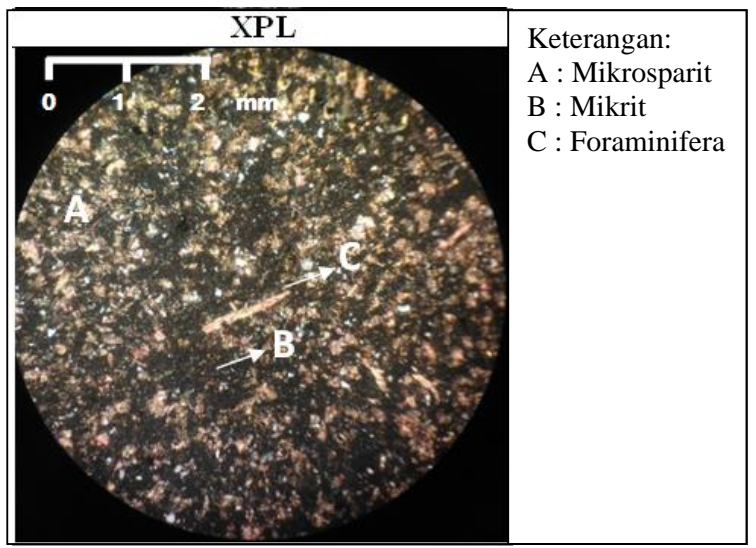

Gambar 9. Kenampakan fasies mudstone pada sampel STA 9C secara mikroskopis.

\section{Fasies Batugamping Kuari $C$}

Penelitian terhadap 12 sampel batugamping Kuari $\mathrm{C}$ menunjukkan bahwa Kuari $\mathrm{C}$ setidaknya tersusun dari 4 jenis fasies yaitu mudstone, wackestone, packstone dan grainstone. Berdasarkan zonasi fasies Pomar (2004), keberadaan fasies-fasies tersebut mengindikasikan batugamping di Kuari C terbentuk di zona back-reef lagoon, baik di bagian outer maupun innernya. Fasies mudstone ditemukan pada sampel STA 3C dan 9C (Gambar 9). Fasies ini dicirikan oleh batugamping abu-abu kehitaman, struktur berlapis, memiliki ukuran butir yang sangat halus dengan keterdapatan fragmen organisme $<10 \%$. Komposisi mikrit yang sangat melimpah menyebabkan warna batuan menjadi gelap.

Fasies wackestone ditemukan pada sampel STA 2C (Gambar 10) dan 5C. Fasies ini dicirikan oleh batugamping abu-abu kehitaman, struktur berlapis, cukup keras dan tersusun dari fragmen material klastik. Material klastik yang menyusun batuan berupa mikrit dan fragmen cangkang 


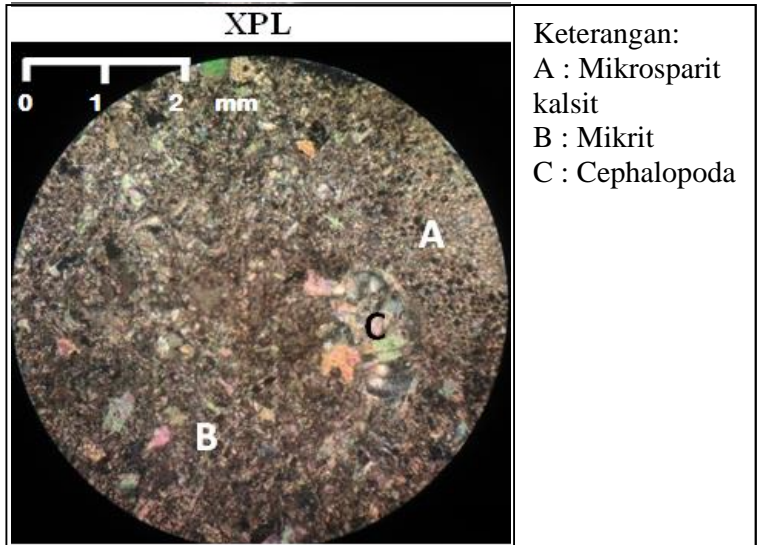

Gambar 10. Kenampakan fasies wackestone pada sampel STA 2C secara mikroskopis.

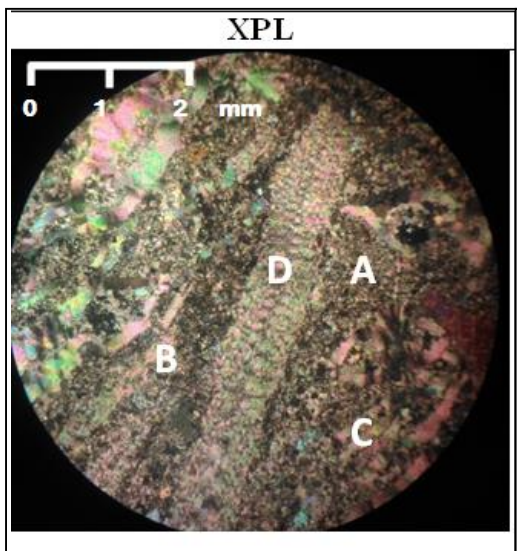

Keterangan: A : Mikrosparit kalsit B : Mikrit C : Foraminifera D : Alga merah

Gambar 11. Kenampakan fasies packstone pada sampel STA 10C secara mikroskopis.

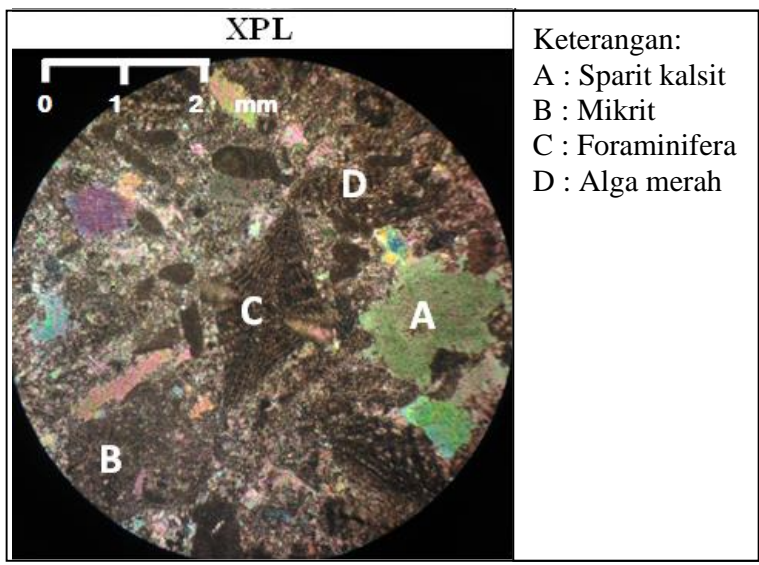

Gambar 12. Kenampakan fasies grainstone pada sampel STA 4C secara mikroskopis.

organik foraminifera dan moluska dengan kelimpahan $>10 \%$. Fasies packstone ditemukan pada sampel STA 10C (Gambar 11) dan 11C. Fasies ini dicirikan oleh batugamping abu-abu kehitaman dengan

struktur masif, cukup keras, dan tersusun dari fragmen material klastik. Material klastik yang menyusun batuan berupa mikrit dan fragmen cangkang organik foraminifera, algae dan moluska yang cukup melimpah sekitar 50\%.

Fasies grainstone ditemukan pada sampel STA 1C, 4C (Gambar 12), 6C, 7C, 8C dan $12 \mathrm{C}$. Fasies ini dicirikan oleh batugamping putih kekuningan, struktur berlapis, dan tersusun dari fragmen material klastik. Material klastik yang menyusun batuan berupa fragmen cangkang organik foraminifera, moluska dan algae. Komposisi mikrit dalam batuan sangat rendah dan hampir tidak ada. Batuan ini juga mengandung banyak sparit sehingga warna batuan menjadi terang.

\section{Hasil Analisis Kualitas Batugamping}

Analisis kualitas batugamping lebih ditekankan terhadap komposisi senyawa $\mathrm{CaO}$ sebagai faktor kimia utama yang menjadi syarat bahan baku pembuatan semen. Persebaran kualitas batugamping Kuari B dan C ditampilkan pada Gambar 13.

\section{Kualitas Batugamping Kuari B}

Analisis terhadap 8 sampel batugamping Kuari B menunjukkan adanya komposisi senyawa $\mathrm{CaO}$ yang cukup tinggi yaitu $49,92 \%$ $55,63 \%$ (Tabel 3). Kandungan senyawa $\mathrm{MgO}$, $\mathrm{SiO}_{2}, \mathrm{Al}_{2} \mathrm{O}_{3}, \mathrm{Fe}_{2} \mathrm{O}_{3}, \mathrm{SO}_{3}$ juga masih memenuhi standar SNI-15-2049-2004. Hal tersebut diinterpretasikan karena karakteristik batugamping Kuari B bersifat grain supported dan rendah akan komposisi lumpur karbonat. Semua sampel batugamping Kuari B tersebut tergolong dalam kualitas batugamping yang baik karena memiliki kadar $\mathrm{CaO}>49 \%$. Nilai tersebut telah memenuhi standar kualitas yang menjadi ketetapan perusahaan sebagai bahan baku pembuatan semen Portland yaitu $>46 \%$.

\section{Kualitas Batugamping Kuari C}

Analisis terhadap 12 sampel batugamping Kuari $\mathrm{C}$ menunjukkan adanya komposisi senyawa $\mathrm{CaO}$ dan senyawa lain yang cukup bervariasi dibandingkan dengan kualitas batugamping Kuari B (Tabel 4). Hal tersebut diinterpretasikan karena karakteristik batugamping Kuari B bersifat matrix supported dan tinggi akan komposisi lumpur karbonat. Hasil analisis kualitas menunjukkan kadar $\mathrm{CaO}$ yang tinggi pada STA 1C, 4C, 6C, 7C, 8C, 10C, 11C dan 12C yaitu $51,88 \%-55,86 \%$. Delapan sampel tersebut 


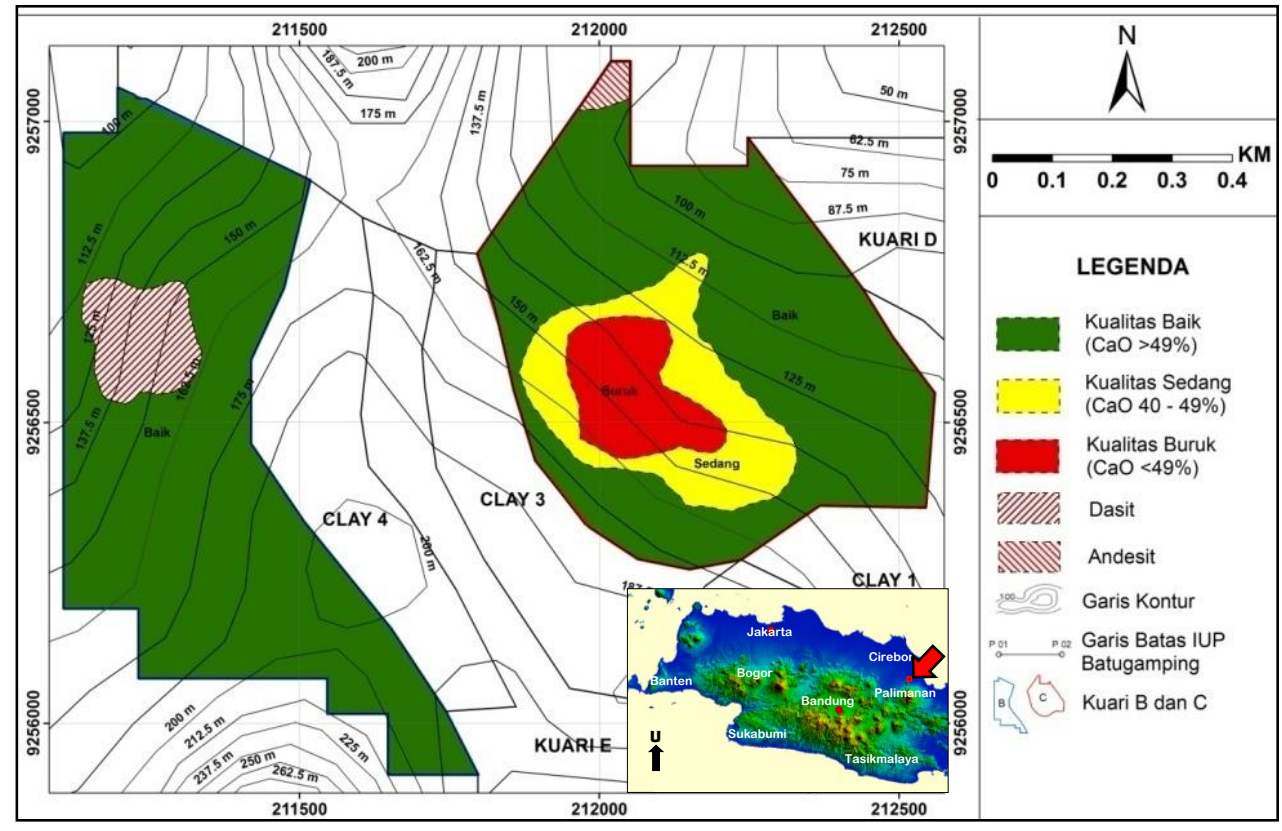

Gambar 13. Peta persebaran kualitas batugamping Kuari B dan C.

Tabel 3. Kualitas batugamping Kuari B dari hasil analisis X-Ray Fluorescence.

\begin{tabular}{cccccccccc}
\hline $\begin{array}{c}\text { No. } \\
\text { Sampel }\end{array}$ & $\mathbf{C a O}$ & $\mathrm{SiO}_{2}$ & $\mathrm{Al}_{2} \mathbf{O}_{3}$ & $\mathrm{Fe}_{2} \mathbf{O}_{3}$ & $\mathbf{M g O}$ & $\mathbf{S O}_{3}$ & $\mathbf{N a}_{2} \mathbf{O}$ & $\mathbf{K}_{2} \mathbf{O}$ & $\mathbf{F e S}_{2}$ \\
\hline STA 1B & 55,62 & 0,80 & 0,75 & 0,29 & 0,92 & 0,18 & 0,48 & 0,04 & 0,01 \\
STA 2B & 55,63 & 1,12 & 0,70 & 0,22 & 0,94 & 0,18 & 0,49 & 0,00 & 0,01 \\
STA 3B & 55,45 & 0,77 & 0,65 & 0,26 & 1,02 & 0,43 & 0,47 & 0,00 & 0,15 \\
STA 4B & 53,19 & 3,89 & 1,54 & 0,52 & 2,56 & 0,26 & 0,45 & 0,01 & 0,05 \\
STA 5B & 55,53 & 0,17 & 0,52 & 0,16 & 0,86 & 0,07 & 0,48 & 0,00 & 0,00 \\
STA 6B & 55,30 & 0,38 & 0,54 & 0,16 & 0,79 & 0,17 & 0,48 & 0,00 & 0,01 \\
STA 7B & 55,46 & 1,23 & 0,67 & 0,19 & 0,97 & 0,21 & 0,46 & 0,00 & 0,03 \\
STA 9B & 49,92 & 8,35 & 1,99 & 1,01 & 1,86 & 0,17 & 0,42 & 0,11 & 0,01 \\
\hline
\end{tabular}

Keterangan:

Kualitas baik

Tabel 4. Kualitas batugamping Kuari $\mathrm{C}$ dari hasil analisis $X$-Ray Fluorescence.

\begin{tabular}{cccccccccc}
\hline $\begin{array}{c}\text { No. } \\
\text { Sampel }\end{array}$ & $\mathbf{C a O}$ & $\mathrm{SiO}_{2}$ & $\mathbf{A l}_{2} \mathbf{O}_{3}$ & $\mathrm{Fe}_{2} \mathbf{O}_{3}$ & $\mathbf{M g O}$ & $\mathbf{S O}_{3}$ & $\mathbf{N a}_{2} \mathbf{O}$ & $\mathbf{K}_{2} \mathbf{O}$ & $\mathbf{F e S}_{2}$ \\
\hline STA 1C & 54,79 & 3,02 & 1,31 & 1,33 & 0,98 & 0,11 & 0,42 & 0,01 & 0,00 \\
STA 2C & 48,35 & 8,06 & 2,17 & 0,80 & 2,73 & 0,33 & 0,37 & 0,18 & 0,09 \\
STA 3C & 27,08 & 40,78 & 7,27 & 3,35 & 3,88 & 1,20 & 0,53 & 0,73 & 0,57 \\
STA 4C & 52,50 & 2,75 & 0,86 & 0,27 & 3,68 & 0,19 & 0,39 & 0,00 & 0,02 \\
STA 5C & 40,01 & 21,14 & 3,82 & 1,36 & 1,78 & 0,27 & 0,30 & 0,42 & 0,06 \\
STA 6C & 51,88 & 6,47 & 1,94 & 0,62 & 0,89 & 0,05 & 0,39 & 0,19 & 0,00 \\
STA 7C & 55,86 & 1,50 & 0,90 & 0,47 & 0,92 & 0,10 & 0,44 & 0,00 & 0,00 \\
STA 8C & 55,30 & 2,14 & 0,97 & 0,45 & 0,89 & 0,09 & 0,44 & 0,00 & 0,00 \\
STA 9C & 30,91 & 34,65 & 7,46 & 2,88 & 2,06 & 1,08 & 0,36 & 0,76 & 0,50 \\
STA 10C & 51,92 & 6,81 & 1,39 & 0,37 & 1,58 & 0,14 & 0,39 & 0,08 & 0,00 \\
STA 11C & 52,04 & 6,39 & 2,40 & 0,62 & 0,93 & 0,06 & 0,37 & 0,08 & 0,00 \\
STA 12C & 55,17 & 3,26 & 1,27 & 0,35 & 0,91 & 0,07 & 0,42 & 0,03 & 0,00 \\
\hline Keterangan: & & & & & & & & \\
\hline & Kualitas baik & & & & & & & \\
\hline & Kualitas sedang & & & & & & & \\
\hline \hline
\end{tabular}


tergolong dalam batugamping kualitas baik karena memiliki kadar $\mathrm{CaO}>49 \%$. Batugamping tersebut bagus digunakan sebagai bahan baku pembuatan semen Portland.

Hasil analisis kualitas sampel STA 2C dan 5C menunjukkan kadar $\mathrm{CaO}$ yang tidak terlalu tinggi yaitu $40,01 \%$ - 48,35\%. Dua sampel tersebut tergolong dalam kualitas batugamping sedang karena memiliki kadar $\mathrm{CaO} 40$ - 49\%. Kadar CaO Sampel STA 2C telah memenuhi standar kualitas minimum sehingga dapat digunakan sebagai bahan baku pembuatan semen Portland secara langsung. Kadar $\mathrm{CaO}$ Sampel STA 5C tidak memenuhi standar kualitas minimum, sehingga tidak bagus digunakan sebagai bahan baku pembuatan semen Portland. Sampel STA 5C bisa digunakan sebagai bahan baku semen Portland apabila dilakukan pencampuran dengan batugamping sampel lain yang memiliki kadar $\mathrm{CaO}$ lebih tinggi.

Hasil analisis kualitas Sampel STA 3C dan 9C menunjukkan kadar $\mathrm{CaO}$ yang sangat rendah yaitu $27,08 \%$ - 30,91\%. Dua sampel tersebut tergolong dalam kualitas batugamping buruk karena memiliki kadar $\mathrm{CaO}<40 \%$. Nilai tersebut tidak memenuhi standar kualitas minimum sehingga tidak bagus digunakan sebagai bahan baku pembuatan semen Portland.

\section{Hubungan Antara Fasies Batugamping terhadap Kualitas Batugamping}

Analisis keterkaitan jenis fasies batugamping terhadap kualitas batugamping Kuari B dan C sebagai bahan baku semen Portland dilakukan dengan pembuatan visualisasi grafik yang menyatakan hubungan kedua variabel penelitian tersebut. Analisis keterkaitan ini dilakukan pada 6 jenis fasies batugamping Kuari B dan C yang terdiri dari fasies grainstone, rudstone, bafflestone, packstone, wackestone dan mudstone terhadap kualitas kimia batugamping yang meliputi kadar $\mathrm{CaO}, \mathrm{MgO}, \mathrm{SiO}_{2}, \mathrm{Al}_{2} \mathrm{O}_{3}, \mathrm{Fe}_{2} \mathrm{O}_{3}$, $\mathrm{SO}_{3}, \mathrm{~K}_{2} \mathrm{O}$, dan $\mathrm{FeS}_{2}(\mathrm{Gambar} 14$ dan 15).

Hasil penelitian menunjukkan bahwa fasies batugamping grainstone, rudstone, bafflestone dan packstone (batugamping grain-supported) cenderung memiliki kadar $\mathrm{CaO}$ lebih tinggi dan kadar $\mathrm{MgO}, \mathrm{SiO}_{2}, \mathrm{Al}_{2} \mathrm{O}_{3}, \mathrm{Fe}_{2} \mathrm{O}_{3}, \mathrm{SO}_{3}, \mathrm{~K}_{2} \mathrm{O}$, dan $\mathrm{FeS}_{2}$ lebih rendah sehingga memiliki nilai ekonomis tinggi, sedangkan fasies wackestone dan mudstone (batugamping matrix-supported) cenderung cenderung memiliki kadar $\mathrm{CaO}$ lebih rendah dan kadar $\mathrm{MgO}, \mathrm{SiO}_{2}, \mathrm{Al}_{2} \mathrm{O}_{3}, \mathrm{Fe}_{2} \mathrm{O}_{3}, \mathrm{SO}_{3}$, $\mathrm{K}_{2} \mathrm{O}$, dan $\mathrm{FeS}_{2}$ lebih tinggi sehingga memiliki nilai ekonomis rendah. Dari hal tersebut dapat disimpulkan pula bahwa Kuari B merupakan kuari yang lebih ekonomis dibandingkan Kuari C pada daerah penelitian.

Tingginya kadar $\mathrm{CaO}$ dan rendahnya kadar $\mathrm{MgO}, \mathrm{SiO}_{2}, \mathrm{Al}_{2} \mathrm{O}_{3}, \mathrm{Fe}_{2} \mathrm{O}_{3}, \mathrm{SO}_{3}, \mathrm{~K}_{2} \mathrm{O}$, dan $\mathrm{FeS}_{2}$ pada batugamping grain-supported diinterpretasikan terjadi karena batugamping jenis ini memiliki persentase butir lebih banyak daripada matriksnya. Kadar $\mathrm{CaO}$ pada batugamping berasal dari butiran batugamping yang terdiri dari fragmen organisme (foraminifera, algae, moluska, koral, dsb) ataupun semen yang terdiri dari aragonit maupun kalsit dengan rumus kimia $\mathrm{CaCO}_{3}$. Sedangkan kadar $\mathrm{MgO}, \mathrm{SiO}_{2}, \mathrm{Al}_{2} \mathrm{O}_{3}, \mathrm{Fe}_{2} \mathrm{O}_{3}, \mathrm{SO}_{3}, \mathrm{~K}_{2} \mathrm{O}$, dan $\mathrm{FeS}_{2}$ dipengaruhi oleh banyak tidaknya mineral lempung maupun mineral lainnya yang menjadi matriks pada batugamping tersebut. Hal sebaliknya terjadi pada batugamping matrixsupported.

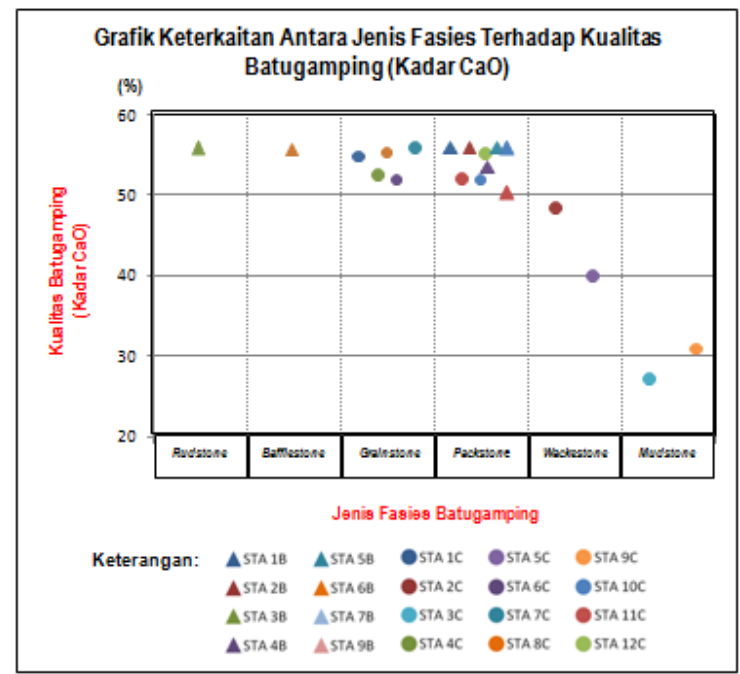

Gambar 14. Grafik keterkaitan antara jenis fasies dengan kualitas batugamping (kadar $\mathrm{CaO}$ ) 


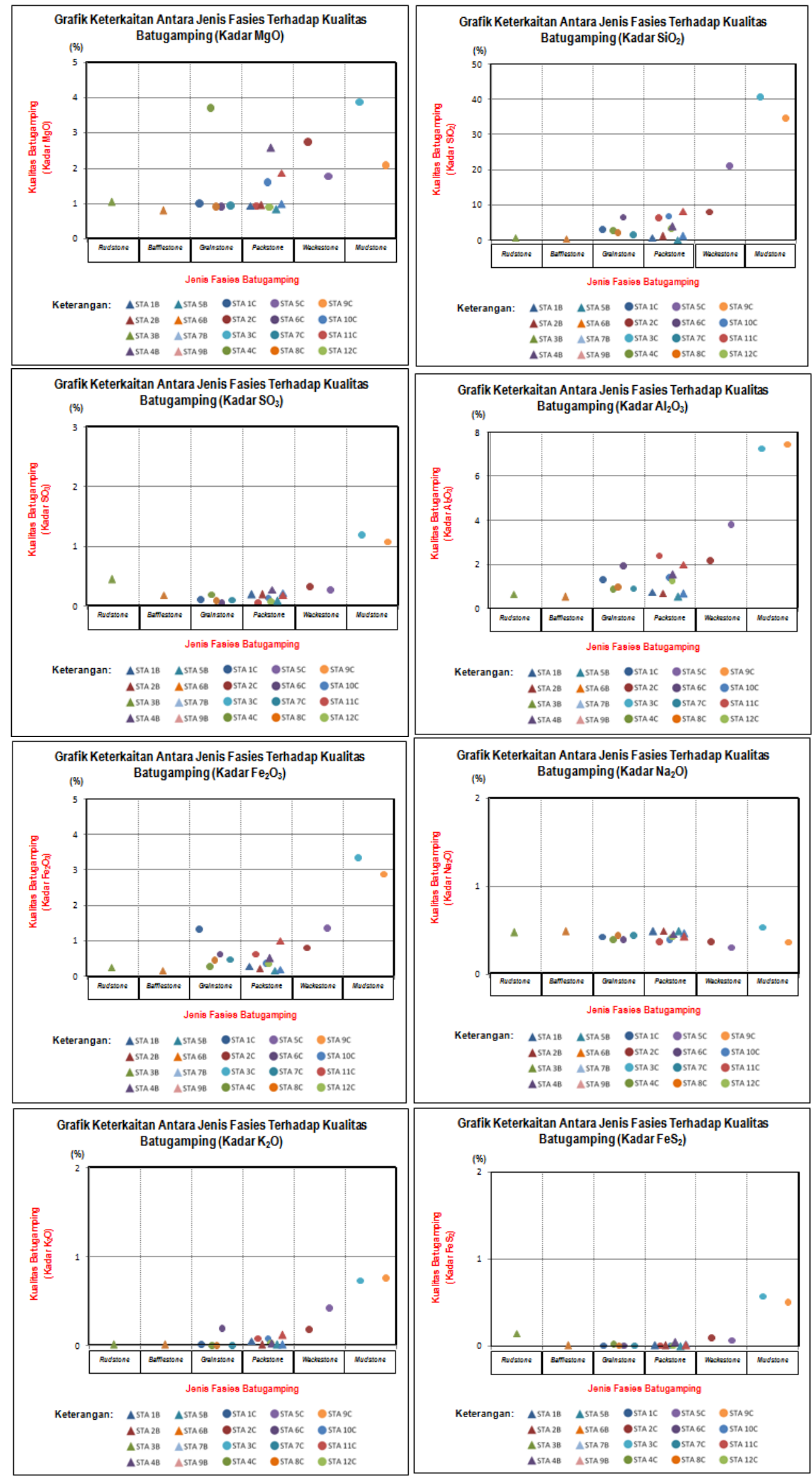

Gambar 15. Grafik keterkaitan antara jenis fasies dengan kualitas batugamping kadar $\mathrm{MgO}, \mathrm{SiO}_{2}, \mathrm{Al}_{2} \mathrm{O}_{3}, \mathrm{Fe}_{2} \mathrm{O}_{3}$, $\mathrm{SO}_{3}, \mathrm{~K}_{2} \mathrm{O}$, dan $\mathrm{FeS}_{2}$. 


\section{KESIMPULAN}

Dari penelitian yang telah dilakukan, dapat disimpulkan bahwa batugamping pada Kuari B dan $\mathrm{C}$ terdiri dari beberapa fasies yang termasuk ke zonasi fasies reef core dan back-reef lagoon. Analisis sampel kualitas batugamping pada Kuari B menunjukkan semua sampelnya berkualitas baik, sedangkan pada Kuari $\mathrm{C}$ didapati sampel berkualitas baik, sedang dan buruk. Berdasarkan kadar $\mathrm{CaO}$ dan senyawa terkait, fasies batugamping yang memiliki banyak fragmen organisme (grain-supported) seperti grainstone, rudstone, bafflestone dan packstone cenderung menunjukkan kualitas baik, sedangkan fasies batugamping yang memiliki sedikit fragmen organisme (matrix-supported) seperti wackestone dan mudstone menghasilkan batugamping dengan kualitas lebih buruk untuk dijadikan bahan semen Portland.

\section{UCAPAN TERIMAKASIH}

Penulis menyampaikan terima kasih kepada Ibu Zerlinda Handietri dan PT Indocement tunggal Prakarsa Tbk Unit Palimanan, Cirebon yang telah memberikan kesempatan untuk melakukan penelitian. Serta pihak-pihak lain yang telah membantu dalam pelaksanaan penelitian ini.

\section{DAFTAR PUSTAKA}

Arpandi, D. dan Patmosukismo, S. 1975. The Cibulakan Formation as One of The Prospective Stratigraphic Unit in The NorthWest Java Basinal Area. Proceedings of 4th Annual Convention of Indonesian Petroleum Association. Hal. 181-210.

Badan Standardisasi Nasional. 2004. SNI-152049-2004 Semen Portland. Jakarta: Badan Standardisasi Nasional.

Brahmantyo, B. dan Bandono. 2006. Klasifikasi Bentuk Muka Bumi (Landform) untuk Pemetaan Geomorfologi pada Skala 1:25.000 dan Aplikasinya untuk Penataan Ruang. Jurnal Geoaplika, Volume 1, Nomor 2. Hal. $071-078$.

Embry, A.F. dan Klovan, J.E. 1971. A Late Devonian Reef Tract On Northeastern Banks Island. Northwest Territories: Bulletin of Canadian Petroleum Geology.

Hewlett, P., dan Liska, M. 2019. Lea's chemistry of cement and concrete ( th $^{\text {th }}$ Eds.). Butterworth-Heinemann.
Loucks, R.G., Kerans, C. dan Janson, X. 2003. Introduction to Carbonate Environments, Facies and Facies Tracts. Diambil dari http://www.beg.utexas.edu/ Imod/_IOLCM01/cm01-step03.html (diakses April 2019)

Marin, J., Winarno, T., dan Rahmadani, U. 2019. Pengaruh Intrusi Basalt terhadap Karakteristik dan Kualitas Batugamping pada Quarry Bukit Karang Putih, Indarung, Padang, Sumatra Barat. Jurnal Geosains dan Teknologi, 2(3), 98-106.

Nurwaskito, A., Amril, F., dan Widodo, S. 2015. Analisis Kualitas Batugamping sebagai Bahan Baku Utama Semen Portland pada PT. Semen Tonasa Provinsi Sulawesi Selatan. Jurnal Geomine, 2(1).

Parorak, C., Yuwanto, S. H., Bahar, H., dan Abdilbar, A. A. 2019. Geologi dan Analisis Kualitas Batugamping Sebagai Bahan Baku Semen Daerah Solokuro dan Sekitarnya, Kecamatan Solokuro, Kabupaten Lamongan, Provinsi Jawa Timur. Prosiding Seminar Teknologi Kebumian dan Kelautan (pp. 222226).

Permana, A. P. 2018. Potensi Batugamping Terumbu Gorontalo sebagai Bahan Galian Industri Berdasarkan Analisis Geokimia Xrf. EnviroScienteae, 14(3), 174-179.

Pomar, L., Brandano, M. dan Westphal, H. 2004. Environmental Factors Influencing SkeletalGrain Sediment Associations: A Critical Review Of Miocene Examples From The Western-Mediterranean. Sedimentology Vol. 51, Hal. 627-651.

Purwoto, Chandra, R. dan Nugroho, E.F. 2011. Peta Geologi Penambangan Batukapur dan Tanah Liat Gunung Kromong, Kecamatan Gempol, Kabupaten Cirebon, Jawa Barat. Cirebon: PT. Indocement Tunggal Prakarsa Tbk. Skala 1:12.000.

Van Bemmelen, R.W. 1949. The Geology of Indonesia Vol. IA. Netherland: Martinus Nijhoff, The Hague.

Wheeler, B. D. 1999. Analysis of limestones and dolomites by X-ray fluorescence. The Rigaku Journal, 16(1), 16-25. 